Literature Reviews

\title{
Changing Accusation in the First Instance: One Step Forward in Criminal Procedure Law
}

\author{
Daniel M. Assad \\ CED Centre Europe, Romania
}

Article history

Received: $31-01-2020$

Revised: $13-03-2020$

Accepted: 25-03-2020

Email: lepaxdoitreipatru@yahoo.ro

\begin{abstract}
Changing the deed's judicial qualification - as a form of changing accusation in the first instance - is a procedural institution, regulated by the Code of penal procedure of Romania. It may be ordered by the court of law, either ex officio or at the parties and prosecutors' demand. In accordance with Article 386 (1) Code of penal procedure, there are two possibilities regarding the changing deed's judicial qualification, beyond providing it to the parties involved in the penal case. One of these implies the defendant's right to require the judgment postponement, while the second refers to the defendant's right to require a new term of judgment in order to prepare the defense along with the lawyer, either appoint by the court of law or designed by the defendant. In this procedural context, the court of law must respect the defendant's rights during the penal trial, including the right to defense, as it is regulated by the Code of penal procedure and the Constitution of Romania as well. Some legal consequences are based on the procedure of solving penal cases, as pointed out in the current review literature.
\end{abstract}

Keywords: Criminal Procedure Law, Defendant's Right, First Instance, Judgment, Lawyer, Right to Defense

\section{Introduction}

The procedure of solving penal cases in the court of first instance is a real challenge for all actors involved in the penal procedure. First of all, the judge is interested in finding truth in the penal case as well as in solving it legally and substantially, based on genuine evidence. Secondly, the defendant is also looking for establishing the innocence and ordering acquittal by the judge. Thirdly, the prosecutor advances the legal theory in the penal case in order to sustain the guilt, if the evidence state so, or the innocence, if the evidence support it. Finally, generally speaking, the entire society is looking for punishing the persons who are found guilty for having committed offenses, in such a way to encourage the principle of respecting laws, on the one hand and acquitting the innocent persons, if there are no evidence in accusation (ECHR, 2018).

The European Convention on Human Rights regulates the presumption of innocence, under Article $6(2)$, as being the main principle which configures the entire procedure in criminal cases (ECHR, 1950). The European document states that "Everyone charged with a criminal offence shall be presumed innocent until proved guilty according to law" and, for this reason, it is very difficult for the courts of law to break this provision as long as it is part of the Romanian legislation (Magherescu, 2019b: 21-24), due to the country's status as a member of the Council of Europe (Council of Europe, The Council of Europe in Brief). The concept is also subordinated to the principle of fair trial, provided by the ICCPR (1966).

The regulations adopted by the European Union institutions are also compulsory for the Government of Bucharest and judicial authorities, due to the Romania's status as a member state of the European Union (ATL, 2005). This is the legal framework adopted by the home authorities, which must be respected by the judicial bodies during the penal proceedings.

In purpose to have a general overview upon the legislation in criminal matters in Romania, especially in the court of first instance, a book published on the topic of changing accusation in the first instance, which contains both theoretical and jurisprudence points of view is of high interest both for theorists and practitioners.

\section{Methodology of Research}

The activity of research on the changing accusation in the first instance has been conducted by the author 
following the terms and directions stated by the qualitative research methodology.

The detailed elements provided by the research conclusions published in the book state the manner in which the other states' legislation regulates the judicial institution of penal procedure law regarding the changing accusation.

The jurisprudence also was analyzed in a comprehensive manner in such a way for readers to understand the real situation happened during the penal trial, both from the defendant's point of view and the prosecutor's one too.

The classical methods of research were combined with the literature review and content synthesis. In this context, the author approaches the topic of research regarding the changing accusation in the first instance in a detailed manner (Magherescu, 2016: 16-17).

\section{Structure and Content}

The second edition of the book on the topic of changing accusation in the first instance was published with the Wolters Kluwer Publishing House in 2016. It contains two titles and six chapters, each of them being also divided in sections for a better understanding by professionals and students as well.

The topics of the contained chapters provide the general aspects on the institution of accusation, exercising judgment within the limits of the stated accusation, as well as the sanction of nullity provided by the Code in cases of infringing the regulation of Article 386 Code of penal procedure (Law no. 135, 2010). All of these issues are subordinated to the main topic of the book regarding the changing accusation in the first instance.

The book is a compilation of theoretical opinions scientifically argued and theories also motivated by the author, being added with practical case law studies gathered from the courts of law decisions pronounced in criminal relevant cases.

A significant part of the book is devoted to the comparative aspects related to the other states' legislation and jurisprudence, which regulate the legal institution of penal procedure law, called "changing accusation".

It is well-known that, in other states' legislation of penal procedure law, the changing accusation is regulated by different institutions of penal procedure law, in accordance with the home entire judicial system the counties belong to. In these circumstances, is is obviously that the author has taken into account all these specific particularities and provided the legal procedure from each country, such as France, Italy, Germany.

The legal institutions regulated by other states' legislation in criminal procedural law are related to the "special questions" and the intervention of "secular law" in France (Jimeno-Bulnes, 2013: 409-
459), "the tripartite division of offenses" in Germany and "legitimate circumstances" in Italy (Chiavario, 2001: 312-316). The special feature of the legal institution of changing accusation is supported by a relevant doctrinal references.

\section{Legal Features of the Changing Accusation}

The author has identified certain elements which feature the legal institution of changing accusation. They refer to the legal conditions which increase such modifications in the first instance, in accordance with the real or personal circumstances the offenses were committed in. In order to reach this aim, the accusation was analyzed in the entire legal values, as well as its exercising both in rem and in personam (Antoniu, 2013: 1-3).

Thus, the accusation is discussed from the point of view of its content, knowing the fact that it is met in practice under several meanings. From this point of view, the author argues that "the function of accusation means the responsibility and right of the prosecutors, as specialized authorities of state to begin the penal investigation against the persons who have infringed the penal provisions, to gather evidence in order to prove accusation, to exercise the penal action against suspected persons, to order the case to be sent to trial, to represent the accusation in front of the court of law in purpose to endorse the penal liability of those who are guilty of having committed offenses" (Magherescu, 2016: 24).

First of all, it is about the accusation which creates the premises for establishing the defendant's guilt, being indifferent if the defendant admits the guilt and signs an agreement with the prosecutor during the investigation phase of penal proceedings (Magherescu, 2019b: 52-54).

Secondly, it is about the function of accusation, established and exercised by the prosecutors in accordance with the evidence gathered by the judicial bodies and administered as well.

Thirdly, the accusation viewed from its substantive-legal size, comprising together the definition of offense committed and the judicial activity, carried out by the judicial bodies.

Finally, the accusation involves procedure of establishing the deed's judicial qualification in accordance with the penal Code or special penal laws and the appropriate article thereof.

Taking into account all these elements the accusation is features with (Marcus, 2012: 357-393), it is obviously that an interdependent relation is connected between all its constituents. It is also appreciated that the procedural institution of accusation is requisite to the final of penal trial in some penal cases. Moreover, during the penal procedure in the first instance, the prosecutor must submit an indubitable accusation, sustained by the genuine evidence as well. 
The factors which determine the changing accusation are either of aggravation or of attenuation of the defendant's criminal liability. On the one hand, the aggravating factors have as consequence the aggravation of the defendant's judicial situation through changing the article which incriminates the criminal acts committed by the defendant. As a consequence, the court of law is entitled to changing the deed's judicial qualification from an offense to another one.

On the other hand, the attenuating factors have as the main role the reduction of accusation submitted by the prosecutor and, in consequence, it concludes in changing the deed's judicial qualification from an aggravated offense to another one. Moreover, the defendant's right to defense must be imperatively protected by the judicial bodies, both in the investigation and judgment phases of penal proceedings. Otherwise, the judicial decision will be pronounced under the sanction of nullity.

Last, but not least, the jurisprudence in criminal cases in the first instance has emphasized that the courts of law are often facing with changing accusation consisting most of the time in changing the deed's judicial qualification.

The penal procedure in the first instance supposes really a legal syllogisms the judges must hold as practitioners of law, in accordance with the provisions in criminal matters. Thus, every time when the judge considers that the accusation formulated by the prosecutor during the investigation phase is wrong and the offense is qualified erroneously, then the judge is entitled to proceed to changing offense's judicial qualification.

\section{Conclusion}

The book concludes that the conflict of penal law created from committing an offense goes to the court of law in order for the state's judicial authorities and society entirely to achieve the right of punishment - jus puniendi - of those perpetrators who are guilty of having committed the offense (Magherescu, 2019a: 44-57).

The author also emphasizes that the procedure of changing accusation in the first instance still has a set of drawbacks and the legislator must take them into consideration in the next period of time in purpose to enhance the legal framework currently into force. The main aims must be focused particularly on the parties' rights during the criminal proceedings, especially in front of the court of law of the first instance.

The author advances a series of eight proposals of $d e$ lege ferenda to be analysed by the legislator for the future. A research project on the topic of changing accusation among theorists would clarify more comprehensive the most important defining elements of the accusation and its changing in the first instance.

For the entire reasons argued in the current literature review, it is evident that the book, on the topic of changing accusation in the first instance, is a useful bibliographic instrument for the law library in Romania. It is designed to both theorists and practitioners in criminal matters.

The book can also be a didactic reference for students, who would like to enhance their knowledge in the field of penal procedure law.

\section{Acknowledgement}

I do express my thanks to the Journal of Social Sciences Editorial Board's members as well as to the anonymous reviewers who appreciated the book review which I submitted in purpose to publish in the 2020 Special Issue of the Journal.

\section{Funding Information}

The work was not financed by any public or private institutions.

\section{Ethics}

There is no ethical issue or interest conflict for the book review published in the Journal of Social Sciences.

\section{References}

Antoniu, G., 2013. The concept of crime under general crisis and globalization. Proceedings of the International Conference Criminal Repression in the Context of the Economic Crisis and the Maximization of Crime at European and Global Level, May 9-10, Medimond - Monduzi Editore, Bologna, pp: 1-3.

ATL, 2005, Ratified by the parliament of romania by law no. 157 of 2005 . Published in the Official Journal of Romania no.

Chiavario, M., 2001. Procedure Penali d'Europa. 2nd End., CEDAM, ISBN-10: 8813229011, pp: 739.

Council of Europe, 2020. The Council of Europe in Brief, Strasbourg.

ECHR, 1950. Entered into force in 1953. Council of Europe, Cedex, Strasbourg.

ECHR, 2018. Decision of 25 January 2018: Case Bikas v. Germany.

ICCPR,

1966. https://www.ohchr.org/en/professionalinterst/pages/ ccpr.aspx

Jimeno-Bulnes, M., 2013. American criminal procedure in a European context. Cardozo J. Int. Comparat. Law, 21: 409-459. DOI: 10.2139/ssrn.2276682 
Law no. 135, 2010. Code of penal procedure of Romania. published in the Official Journal of Romania, no.

Magherescu, D., 2016. Modificarea invinuirii in prima instanta (Aspecte comparative). Wolters Kluwer Publishing House, Bucharest.

ISBN: 978-606-677-017-0, pp: 224.

Magherescu, D., 2019a. Admission of guilt agreement as a special procedure of the penal trial-a particular attention upon the Romanian model. J. Soc. Sci., 15: 44-57. DOI: $10.3844 /$ jssp.2019.44.57
Magherescu, D., 2019b. Recunoasterea Vinovatiei si Aplicarea Pedepsei. 1st Edn., Editura Hamangiu, ISBN-10: 6062713448, pp: 216.

Marcus, K.L., 2012. Accusation in mirror. L.U. Chicago Law J., 2: 357-393. 